\title{
Carcass Traits, Meat Characteristics, and Economic Viability of Grazing Nellore Cattle Produced Under Different Supplementation Strategies in the Tropics
}

\section{Jenifer Maira Lima Ramos}

Universidade Federal Rural da Amazonia

Julián Andrés Castillo Vargas

Universidade Federal Rural da Amazonia

Evellyn Aryane Lopes Diniz

Universidade Federal Rural da Amazonia

Natália Gomes Lacerda

Universidade Federal Rural da Amazonia

Rafael Mezzomo

Universidade Federal Rural da Amazonia

Kaliandra Souza Alves

Universidade Federal Rural da Amazonia

Luis Rennan Sampaio Oliveira

Universidade Federal Rural da Amazonia

João Paulo Borges de Loureiro

Universidade Federal Rural da Amazonia

Poliana Ramos da Silva

Universidade Federal Rural da Amazonia

Daiany Iris Gomes ( $\nabla$ daiany.i.gomes@gmail.com )

Universidade Federal Rural da Amazonia https://orcid.org/0000-0001-7850-3650

\section{Research Article}

Keywords: Bulls, carcass trait, expense, meat trait, profitability indicator

Posted Date: December 6th, 2021

DOI: https://doi.org/10.21203/rs.3.rs-1075720/v1

License: (c) (i) This work is licensed under a Creative Commons Attribution 4.0 International License.

Read Full License 


\section{Abstract}

This study explored the effects of different supplementation strategies in the dry and rainy seasons in the tropics on the carcass traits, meat quality, and economic viability of Nellore cattle produced under grazing conditions. For this purpose, twenty-eight non-castrated male animals (18 months) with an initial body weight of $327.93 \pm 4.22 \mathrm{~kg}$ were used. The animals were equitably distributed in a randomized complete design thorough four supplementation strategies as follows: i) mineral supplementation (MS) in both dry and rainy seasons (MS/MS), ii) MS in the dry season and concentrate supplementation (CS) in the rainy season (MS/CS), iii) CS in the dry season and MS in the rainy season (CS/MS), and iv) CS in both dry and rainy seasons (CS/CS). Thereafter, carcass traits, primary carcass cut yields, meat quality traits, chemical composition of meat, and economic viability of cattle production across different supplementation strategies were determined. Data revealed that animals under CS/CS showed the greatest $(P<0.01)$ hot carcass weights among the other supplementation strategies evaluated. Conversely, supplementation strategy did not affect $(\mathrm{P}>0.05)$ carcass traits (the ribeye area, final $\mathrm{pH}$, and forequarter), meat quality traits (shear force, myofibrillar fragment index, sarcomere length, and color), and meat chemical composition (crude protein, fat, and moisture) of the animals. The effective operational cost, total cost, gross revenue, and profit of animals under CS/CS showed the greatest values, whereas the lowest ones were obtained for the animals under MS/MS. In conclusion, data suggest that concentrate supplementation during at least one season (dry or rainy) produces similar meat quality traits and chemical composition of meat, but different hot carcass weight, backfat thickness and hindquarter proportion to those observed when animals were supplemented with concentrate in both seasons. Additionally, CS/CS animals, despite having a higher total cost, have greater profitability when raised in tropical pasture.

\section{Introduction}

Beef cattle raised under tropical conditions use the pasture as the main feed source across the whole year (Lobato et al., 2014); however, even when forage is well managed, there are variations in its quality and quantity due to changes in climate conditions, which are characterized by the occurrence of the dry and rainy seasons in the tropics (Pezzopane et al., 2018). In this context, the amount of digestible nutrients ingested by grazing animals may change across the year, which may infer in their developmental stage, carcass traits, and beef quality (De Paula et al., 2019).

To overcome the variations in nutrient inputs, grazing tropical beef cattle is commonly supplemented with concentrate in intensive production systems (Detmann et al., 2014); however, beyond supplementation level, the choice for an adequate supplementation strategy during the dry and rainy seasons may differentially infer in the growth rate of the animals (Sampaio et al., 2017). In general, a restriction of nutrients occurs in the dry season, whereas an increase of nutrient supply to animals goes in the rainy season; hence, the dynamics of nutrient across these seasons influences the body composition and weight gain (Modzelewska-Kapituła and Nogalski, 2016; Oksbjerg and Therkildsen, 2017; Silva et al., 
2020). Therefore, the selection of a correct supplementation strategy may positively affect the carcass characteristics of cattle, thereby influencing the cattle production economic viability as well.

Studies with beef cattle under tropical conditions have focused on the evaluation of the effects of supplementation levels during the dry season and its potential effects on growth and performance parameters during the subsequent rainy season (Roth et al., 2017; Sampaio et al., 2017; Roth et al., 2018). Nevertheless, to date, no studies have yet conducted evaluating the effects of different supplementation strategies considering the dry and rainy seasons, on the carcass traits, meat quality, and economic viability of Nellore beef cattle production. This information may be valuable for designing sustainable cattle nutrition strategies in the tropics to meet world market preferences across the year, considering that cattle production in this region accounts for half of cattle worldwide (Rubio Lozano et al., 2021). Thus, this study evaluated the effects of different supplementation strategies across the dry and rainy seasons in the tropics on the carcass characteristics, meat quality, and economic viability of grazing Nellore steers. The hypothesis of this study focused on that concentrate supplementation during at least one season (dry or rainy) produces similar carcass traits, meat quality traits, and chemical composition of meat to those observed when animal are supplemented with concentrate in both seasons.

\section{Material And Methods}

\section{Location, animals, treatments, and experimental diets}

The experiment was conducted at the beef cattle station of the Federal Rural University of Amazon/UFRA-Parauapebas Campus, Para, Brazil (6 4'25.53"S; 4948'54.57"W).

Twenty-eight young Nellore bulls, 18 months of age and $327.93 \pm 4.22 \mathrm{~kg}$ body weight were equitably distributed in the treatments represented in Table 1. The experimental area consisted of eight paddocks of one hectare each, composed by Urochloa brizantha, cv. Marandu, which was not grazed during 60 days before the beginning of the experiment. Animals were continuously moved through four paddocks in the entire experiment. Each treatment group of animals was sequentially moved from one paddock to the next every 7 days to minimize potential effects of different paddock conditions on the response to supplementation strategies. 
Table 1

Description of supplementation strategies evaluated in young Nellore bulls

\begin{tabular}{|c|c|c|}
\hline Supplementation strategy a & Dry season & Rainy season \\
\hline MS/MS & Mineral salt & Mineral salt \\
\hline $\mathrm{MS} / \mathrm{CS}$ & Mineral salt & Concentrate at $8 \mathrm{~g} / \mathrm{kg} \mathrm{BW}$ \\
\hline $\mathrm{CS} / \mathrm{MS}$ & Concentrate at $8 \mathrm{~g} / \mathrm{kg} \mathrm{BW}$ & Mineral salt \\
\hline $\mathrm{CS} / \mathrm{CS}$ & Concentrate at $8 \mathrm{~g} / \mathrm{kg} \mathrm{BW}$ & Concentrate at $8 \mathrm{~g} / \mathrm{kg} \mathrm{BW}$ \\
\hline
\end{tabular}

The experimental period lasted 293 days, with 20 days for the animals' adaptation to paddocks and experimental diets. The first part of the experimental period was developed during the dry period (from $06 / 29$ a 10/19, 112 days), and the second part during the rainy period (from 10/20 to 03/29, 161 days). The concentrate supplement was offered in amounts of $0.8 \%$ of the animals' body weight, while mineral supplement was provided at $0.10 \mathrm{~kg} / \mathrm{animal}$. Both supplements were formulated considering forage composition in each period (Table 2) and in accordance with cattle nutritional requirements for providing an average daily gain of $1 \mathrm{~kg}$, in accordance with BR Corte (Valadares Filho et al., 2016) recommendations. Supplements (concentrate or mineral salt) for each treatment were provided daily at 10:00 am in a covered feeder $(0.33 \mathrm{~m} /$ animal) located in each paddock and water was available at libitum. 
Table 2

Ingredients and chemical composition of forage, concentrate, and mineral salts used during the dry and rainy seasons

\begin{tabular}{|c|c|c|c|c|}
\hline \multirow[t]{2}{*}{ Ingredient (\% dry matter) } & \multicolumn{2}{|l|}{ Dry season } & \multicolumn{2}{|l|}{ Rainy season } \\
\hline & Concentrate & Forage $^{a}$ & Concentrate & Forage $^{b}$ \\
\hline Ground grain corn & 76.68 & - & 81.79 & - \\
\hline Soybean meal & 17.04 & - & 12.84 & - \\
\hline Mineral salt ${ }^{\mathrm{C}}$ & 3.53 & - & 3.58 & - \\
\hline Urea & 2.75 & - & 1.79 & - \\
\hline \multicolumn{5}{|c|}{ Chemical composition (\%DM) } \\
\hline Dry matter (\% as fed) & 89.96 & 88.82 & 88.46 & 90.67 \\
\hline Organic matter & 92.32 & 88.81 & 94.51 & 90.86 \\
\hline Crude protein & 22.86 & 8.68 & 19.10 & 11.28 \\
\hline Ether extract & 2.99 & 1.68 & 4.55 & 2.17 \\
\hline Neutral detergent fiber & 15.21 & 67.81 & 15.77 & 58.8 \\
\hline Lignin & 1.68 & 4.64 & 0.82 & 2.81 \\
\hline \multicolumn{5}{|c|}{ a Mean value of samples obtained by hand-plucking method during the dry season. } \\
\hline \multicolumn{5}{|c|}{ b Mean value of samples obtained by hand-plucking method during the rainy season. } \\
\hline $\begin{array}{l}\text { Mineral salt composition } \\
\mathrm{mg} \mathrm{Fe} / \mathrm{kg} ; 90 \mathrm{mg} \mathrm{l} / \mathrm{kg} ; 20\end{array}$ & $\begin{array}{l}\mathrm{Ca} / \mathrm{kg} ; 74 \mathrm{~g} \mathrm{P} \\
\mathrm{An} / \mathrm{kg} ; 15 \mathrm{mg}\end{array}$ & $\begin{array}{l}24 \mathrm{~g} \mathrm{~S} / \mathrm{kg} \\
\mathrm{g} ; 5270 \mathrm{~m}\end{array}$ & $\begin{array}{l}\mathrm{Co} / \mathrm{kg} ; 1250 \mathrm{~m} \\
\text { and } 1740 \mathrm{mg} \mathrm{F}\end{array}$ & /kg; 1795 \\
\hline
\end{tabular}

\section{Chemical analysis of forage and supplements}

Samples of forage and concentrate supplement (one-mm ground) were analyzed for dry matter (DM; Method 934.01), ash (Method 942.05), crude protein (CP, Method 984.13), and ether extract (EE; Method 920.39) in accordance with AOAC (2005) recommendations. Neutral detergent fiber (NDF) analysis was conducted following the procedure depicted by Van Soest et al. (1991) with modifications suggested by Mertens et al. (2002), and the lignin content was estimated as described by Van Soest and Robertson (1985). Mineral salt chemical composition was provided by the manufacturer (DSM ${ }^{\circledR}$, Marabá, PA, Brazil). Table 2 shows the chemical composition of forage and supplements.

\section{Slaughter, pH measurements, and carcass traits}

At the end of the experimental period, cattle were fasted for 16 hours, weighed to determine the body weight at slaughter (BWS), and slaughter in a commercial slaughterhouse of Parauapebas City, following 
the Sanitary and Industrial Inspection Regulations for Animal Origin Products (BRASIL, 1997). After animal slaughter, $\mathrm{pH}$ was measured in the Longissimus muscle in a section made at the 12th rib using a direct puncture $\mathrm{pH}$ meter (HI 99163 Model - Hanna Instruments). The carcass was separated into two half carcasses, whose weights were obtained to measure the hot carcass weight ( $\mathrm{HCW} ; \mathrm{kg})$, then cooled in a cold room for 24 hours. After cooling, the $\mathrm{pH}$ in the Longissimus muscle was again measured.

Determination of the yield of hot carcasses was performed in relation to BWS using the following equation: hot carcass yield $(\mathrm{HCY} ; \%)=(\mathrm{HCW} / \mathrm{BWS}) \times 100$. The ribeye area $\left(\mathrm{cm}^{2}\right)$ and backfat thickness were measured on the left side of each carcass following the procedure suggested by Lacerda et al. (2021). The right half carcass of each animal was separated into the following primary cuts: forequarter (composed of the shoulder, neck, foreleg arm and five ribs), and hindquarter (composed of posterior part of the carcass, separated from the forequarter between the fifth and sixth ribs). The cuts were separately weighed, and their proportions were calculated with respect to the appropriate half of the cold carcass, in accordance with (Prado et al., 2015) recommendations.

\section{Longissimus muscle processing and meat quality evaluation}

A sample was taken from the left half carcass of each animal, between the 12th and 13th ribs comprising the Longissimus dorsi muscle for meat quality analysis. The $2.54 \mathrm{~cm}$ thick steaks were vacuum-packed and immediately frozen at $-20^{\circ} \mathrm{C}$ for further determination meat quality traits (shear force, myofibrillar fragmentation index, sarcomere length and color), and chemical composition of the meat (i.e., moisture, crude protein, and fat).

The shear force was determined following the procedures described by Lacerda et al. (2021), while the Myofibrillar fragmentation index was obtained as suggested by Culler et al. (1978), with modifications proposed by Hopkins et al. (2004). Sarcomere length was determined by using laser diffraction (indirect method), following the procedure described by Silva et al. (2017).

\section{Meat color}

Steaks were removed from packages under vacuum and exposed for 30 minutes in a refrigerated environment $\left(4^{\circ} \mathrm{C}\right)$ to allow oxygenation. The parameters evaluated were $L, a^{*}$, and $b^{*}$ using the CIELab scale, where $L$ represents the luminosity $\left(L=0\right.$, black; and $L=100$, white), $a^{*}$ represents the intensity of red $\left(a^{*}=0\right.$ to -60 , green; and $a^{*}=0$ to +60 , red) and $b^{*}$ represents the intensity of yellow ( $b^{*}=0$ to -60 , blue; and $b^{\star}=0$ to +60 , yellow). Three determinations were made at different points on the Longissimus surface. The color evaluation was conducted using a colorimeter, with a D65 illuminant, $8^{\circ}$ viewing angle, and $10^{\circ}$ observer standard, according to the CIE (1986) specifications.

\section{Chemical composition of meat}

Samples from Longissumus dorsi were dehydrated in a freeze dryer for $48 \mathrm{~h}$ to determine the DM content. Thereafter, samples were defatted by successive washing with petroleum ether to obtain the pre-defatted 
DM content. And finally, samples were processed in a ball mill $(1 \mathrm{~mm})$ and the DM (Method 934.01), CP (Method 984.13), and EE (Method 920.39) were performed in accordance with AOAC (2005) recommendations. The natural matter content (totaling $100 \%$ sample) was determined considering the protein and ether extract levels in the pre-defatted dry matter samples and the weight of the samples subjected to pre-defatting.

\section{Economic feasibility assessments}

An economic analysis of supplementation strategies was performed, using the budget analysis system developed by Shang (1990) as a reference. The following economic indicators were determined:

Supplementation cost in the dry and rainy seasons: Cost of the supplement consumed per animal per day.

Effective operational cost (EOC): Expenses related to machinery, labor, equipment, and supplement.

Total cost: EOC + purchase of animals.

Gross Revenue: Calculated according to the amount of carcass produced from each supplementation strategy and the sales price of the product (US $\$ 2.65 / \mathrm{kg}$ carcass)

Profit: Gross revenue - total cost

Profit index $=($ Total cost $/ G R) \times 100$

All values were expressed in American dollars (USD). Prices of feedstuff were obtained from markets in the Para state of Brazil, during October 2017.

\section{Statistical analyses}

All statistical analysis were performed using the SAS ${ }^{\circledR}$ software (version 9.4; SAS Institute Inc., Cary, NC, USA). Data on variables related to meat carcass traits, meat quality traits, and chemical composition of meat were analyzed as a completely randomized design applying the proc MIXED of SAS, in accordance with the model described below:

$Y_{i j}=\mu+T_{j}+\varepsilon_{i j k}$

where $\mathrm{Y}_{\mathrm{ij}}$ is the explored variable; $\mu$ is the overall mean; $\mathrm{Tj}$ is the treatment effect; and $\varepsilon_{\mathrm{ij}}$ is the residual error. The treatments means was compared performing a Tukey Test (Steel and Torrie, 1980) and the Least Squares Means of treatments were calculated by the LSMEANS statement of the proc MIXED. All treatment comparisons were conducted using a significance level of $0.05(P<0.05)$. Trends towards significance were considered when $\mathrm{P}$ value ranged from 0.05 and 0.10 .

Data on economic variables (expenses and profitability) were analyzed by descriptive statistics using the proc MEANS of SAS. 


\section{Results}

\section{Carcass traits and primary carcass cut yields}

Data revealed that cattle supplemented with concentrate in both dry and rainy seasons (CS/CS) showed the greatest hot carcass weights $(P<0.01)$ compared to animals under other supplementation strategies (Table 3). However, cattle supplemented with concentrate in at least one season (i.e., MS/CS and CS/MS) showed similar $(P>0.05)$ hot carcass weights (Table 3$)$. Cattle without concentrate supplementation in both seasons (i.e., MS/MS) showed the lowest $(P<0.01)$ hot carcass weights among the supplementation strategies evaluated (Table 3 ). The type of supplementation strategy did not affect $(\mathrm{P} \geq$ 0.05 ) the final $\mathrm{pH}$, hot carcass yield, and ribeye area (Table 3); however, there was a tendency $(P=0.058)$ to increase the backfat thickness for animals that were supplemented with concentrate during the dry season (i.e., CS/MS and CS/CS).

Table 3

Carcass traits and primary carcass cut yields from young bulls subjected to different supplementation strategies

\begin{tabular}{|c|c|c|c|c|c|c|}
\hline \multirow[t]{2}{*}{ Variables } & \multicolumn{4}{|c|}{ Supplementation strategy 1} & \multirow[t]{2}{*}{ SEM } & \multirow[t]{2}{*}{ P-value ${ }^{2}$} \\
\hline & MS/MS & MS/CS & CS/MS & CS/CS & & \\
\hline \multicolumn{7}{|l|}{ Carcass traits } \\
\hline Hot carcass weight, kg & $231.21^{\mathrm{C}}$ & $247.51^{\mathrm{B}}$ & $264.08^{B}$ & $276.71^{A}$ & 4.534 & $<0.01$ \\
\hline Final $\mathrm{pH}, 24 \mathrm{~h}$ & 5.82 & 5.87 & 5.74 & 5.88 & 0.062 & 0.266 \\
\hline Hot carcass yield, $\%$ & 53.87 & 52.75 & 53.09 & 52.42 & 0.495 & 0.166 \\
\hline Ribeye area, $\mathrm{cm}^{2}$ & 64.37 & 63.05 & 64.48 & 63.30 & 2.880 & 0.974 \\
\hline Backfat thickness, mm & 1.98 & 1.94 & 3.39 & 3.10 & 0.460 & 0.058 \\
\hline \multicolumn{7}{|c|}{ Primary carcass cut yields } \\
\hline Forequarter, \% & 42.04 & 42.16 & 41.67 & 42.80 & 0.545 & 0.499 \\
\hline Hindquarter, \% & 47.50 & 48.08 & 47.41 & 46.10 & 0.514 & 0.056 \\
\hline \multicolumn{7}{|c|}{$\begin{array}{l}{ }^{1} \mathrm{MS} / \mathrm{MS} \text { : mineral supplementation during both, dry and rainy seasons; MS/CS: mineral } \\
\text { supplementation during the dry sea son and concentrate supplementation during the rainy season; } \\
\mathrm{CS} / \mathrm{MS} \text { : concentrate supplementation during the dry season and mineral supplementation during the } \\
\text { rainy season; CS/CS: concentrate supplementation during both, dry and rainy seasons. }\end{array}$} \\
\hline
\end{tabular}

Data showed that supplementation strategy did not influence $(P=0.499)$ the forequarter yield in bulls (Table 3). Conversely, the hindquarter yield showed a tendency $(P=0.056)$ to be greater for animals that 
were supplemented with concentrate in the rainy season (i.e., MS/CS).

\section{Quality and chemical composition of meat}

There was no effect $(P>0.05)$ of supplementation strategy on meat quality traits (i.e., shear force, myofibrillar fragment index, sarcomere length, and color parameters) of bulls (Table 4). Chemical composition of meat (i.e., moisture, crude protein, and fat) was not affected ( $P>0.05)$ as well (Table 4$)$.

Table 4

Quality and chemical composition of meat from young bulls subjected to different supplementation strategies

\begin{tabular}{|c|c|c|c|c|c|c|}
\hline \multirow[t]{2}{*}{ Variables } & \multicolumn{4}{|c|}{ Supplementation strategy ${ }^{1}$} & \multirow[t]{2}{*}{ SEM } & \multirow[t]{2}{*}{ P-value ${ }^{2}$} \\
\hline & MS/MS & MS/CS & CS/MS & CS/CS & & \\
\hline \multicolumn{7}{|l|}{ Meat quality traits } \\
\hline Shear force, kgf & 5.15 & 4.76 & 5.20 & 4.68 & 0.783 & 0.938 \\
\hline Myofibrillar fragment index & 54.85 & 43.13 & 39.20 & 57.61 & 0.886 & 0.408 \\
\hline Sarcomere length, $\mu \mathrm{m}$ & 1.45 & 1.45 & 1.53 & 1.41 & 0.043 & 0.248 \\
\hline \multicolumn{7}{|l|}{ Color } \\
\hline L & 35.08 & 34.83 & 36.47 & 35.23 & 0.857 & 0.512 \\
\hline$a^{*}$ & 13.33 & 13.54 & 14.13 & 12.16 & 0.897 & 0.483 \\
\hline$b^{*}$ & 2.01 & 2.12 & 3.04 & 2.05 & 0.546 & 0.507 \\
\hline \multicolumn{7}{|c|}{ Chemical composition of meat, $\%$} \\
\hline Moisture & 77.45 & 77.22 & 76.99 & 77.19 & 0.168 & 0.341 \\
\hline Crude protein & 20.73 & 20.95 & 21.25 & 20.93 & 0.160 & 0.180 \\
\hline Fat & 0.75 & 0.72 & 0.78 & 0.83 & 0.132 & 0.933 \\
\hline \multicolumn{7}{|c|}{$\begin{array}{l}{ }^{1} \mathrm{MS} / \mathrm{MS} \text { : mineral supplementation during both, dry and rainy seasons; MS/CS: mineral } \\
\text { supplementation during the dry season and concentrate supplementation during the rainy season; } \\
\text { CS/MS: concentrate supplementation during the dry season and mineral supplementation during the } \\
\text { rainy season; CS/CS: concentrate supplementation during both, dry and rainy seasons. }\end{array}$} \\
\hline
\end{tabular}

\section{Economic feasibility assessments}

Economic indicators associated with expenses revealed that supplementation strategies with concentrate during the dry and/or rainy seasons (i.e., MS/CS, CS/MS, and CS/CS) showed the greatest supplementation expense values (Table 5). The EOC and total cost of animals showed the highest values for the supplementation strategy with concentrate in both, the dry and rainy seasons (i.e., CS/CS), 
whereas the MS/MS supplementation strategy showed the lowest values (Table 5). The profitability indicators indicated that supplementation strategy with concentrate in both, the dry and rainy seasons (i.e., CS/CS) produced the highest gross revenue, profit, and profit index, whereas the MS/MS supplementation strategy showed the lowest values (Table 5).

Table 5

Economic analysis of supplementation and profit of young Nellore bulls subjected to different supplementation strategies

\begin{tabular}{|c|c|c|c|c|}
\hline \multirow[t]{2}{*}{ Variables } & \multicolumn{4}{|c|}{ Supplementation strategy ${ }^{3}$} \\
\hline & MS/MS & MS/CS & CS/MS & $\mathrm{CS} / \mathrm{CS}$ \\
\hline \multicolumn{5}{|l|}{ Expenses } \\
\hline Supplementation cost - dry season ${ }^{1}$ & 0.07 & 0.07 & 0.41 & 0.41 \\
\hline Supplementation cost - rainy season ${ }^{2}$ & 0.07 & 0.58 & 0.07 & 0.61 \\
\hline EOC, \$/animal & 43.97 & 128.45 & 87.62 & 170.37 \\
\hline EOC, $\$ / \mathrm{kg}$ of body weight & 0.46 & 0.80 & 0.60 & 0.84 \\
\hline Total cost, \$/animal & 581.34 & 651.16 & 614.16 & 702.94 \\
\hline \multicolumn{5}{|l|}{ Profitability } \\
\hline Gross revenue, $\$$ / animal & 612.30 & 715.54 & 684.05 & 787.95 \\
\hline Profit, \$/ animal & 30.96 & 64.38 & 69.89 & 85.01 \\
\hline Profit index, \% of gross revenue & 4.61 & 8.79 & 9.77 & 10.78 \\
\hline \multicolumn{5}{|c|}{$1,2 \$ /$ animal/day; EOC = effective operational cost; Total cost = EOC + purchase of animals. } \\
\hline \multicolumn{5}{|c|}{$\begin{array}{l}{ }^{3} \mathrm{MS} / \mathrm{MS} \text { : mineral supplementation during both, dry and rainy seasons; MS/CS: mineral } \\
\text { supplementation during the dry season and concentrate supplementation during the rainy season; } \\
\mathrm{CS} / \mathrm{MS} \text { : concentrate supplementation during the dry season and mineral supplementation during the } \\
\text { rainy season; CS/CS: concentrate supplementation during both, dry and rainy seasons. Comparison } \\
\text { between variables was performed from their descriptive statistics due to lack of replications within } \\
\text { treatments. }\end{array}$} \\
\hline
\end{tabular}

\section{Discussion}

This study explored the effects of different supplementation strategies adopted during the dry and rainy seasons in the tropics, on the carcass traits, meat quality, and economic viability of Nellore steers production. As expected, a quantitative restriction produced by the supply of different energy density diets across the seasons (i.e., different supplementation strategies), resulted in different hot carcass weights. This agrees with Silva et al. (2020) findings, who showed that quantitative feed restrictions in Nellore 
cattle associated to different nutritional plans, influence the growth rate, body composition, and performance of the animals.

A reduction in the forage quality associated with the MS of the animals in the dry season (i.e., MS/MS and MS/CS groups), resulted in the lowest hot carcass weights (i.e., animals with the lightest carcasses); however, animals supplemented with concentrate in both periods (i.e., CS/CS) showed the highest values. This indicates that the selection of the season period when animals are supplemented with concentrate under tropical conditions may have a significant influence in their performance. Animals under MS/CS and CS/MS supplementation strategies produced higher hot carcass weights that those of animals supplemented with mineral salt in both seasons (i.e., MS/MS). Hence, animal supplementation with concentrate in at least one season presented a compensatory gain, which conforms to Hornick et al. (1998) and Sampaio et al. (2017) findings, who observed a compensatory gain in Nellore cattle after feed restriction.

Concomitantly, the concentrate supplementation in both dry and rainy seasons (i.e., CS/CS) produced animals with the highest hot carcass weight among the other supplementation strategies evaluated. This may be due to the highest energy density of the diet supplied in this supplementation strategy compared to others explored. It is known that the adequate supply of protein and energy requirements contributes to the growth of ruminal microorganisms, increasing fiber digestibility and, consequently, improving the response to weight gain in cattle (Detmann et al., 2014); in addition, the greater availability of concentrate leads to an increase in the propionate concentration in the rumen, thereby enhancing glucose production, and this fact is positively associated with muscle growth (Ladeira et al., 2016; Wicks et al., 2019). The latest effect was also in accordance with the highest hot carcass weights observed in animals under $\mathrm{MS} / \mathrm{CS}, \mathrm{CS} / \mathrm{MS}$, and CS/CS nutritional strategies, suggesting that an improvement in nutritional inputs in at least one of the climatic seasons (i.e., dry, or rainy), may be advantageous over the traditional finishing system in tropical pastures, without concentrate supplementation (i.e., MS/MS).

Data revealed that backfat thickness tended to be lower for animals supplemented with mineral salt in the dry season (i.e., MS/MS and MS/CS) compared to other supplementation strategies. This fact demonstrates that animals under feed restriction in the dry season prioritize the growth of visceral organs instead of depositing subcutaneous fat (Silva et al., 2020). Regarding ribeye area, no differences were observed across supplementation strategies; nevertheless, animals under MS/MS and MS/CS supplementation strategies tended to produce the highest hindquarter yields, demonstrating the priority in muscle deposition over the adipose tissue deposition, which is in line with other studies (Hornick et al., 1998; Silva et al., 2017).

Diets with low protein and energy contents, such as provided to grazing animals during the dry period in the tropics (Rufino et al., 2016) may reduce muscle glycogen content, thereby affecting the pH of meat (Vestergaard et al., 2000); however, contrary to the expectations, this response was not observed in this study for the animals supplemented with mineral salt in the dry season (i.e., MS/MS and MS/CS). Furthermore, no differences were observed for any meat quality traits (i.e., shear force, myofibrillar 
fragment index, sarcomer lengh, and color) and chemical composition of meat (i.e., moisture, crude protein, and fat), both group characteristics related to postmortem muscle proteolysis and highly associated with in vivo muscle turnover (Therkildsen et al., 2008).

A possible explanation to these contradictory results may be due to the long refeeding time adopted in this study because this one considered 161 days of the rainy season. According to Therkildsen (2005), the effects of compensatory growth on muscle protein turnover depends on time. Additionally, protein turnover between continuous and compensatory animal growth becomes equivalent for re-feeding periods greater than 77 days. Additionally, forage with a high level of crude protein $(112.8 \mathrm{~g} / \mathrm{kg} \mathrm{DM})$ and lower neutral fiber $(678.1 \mathrm{~g} / \mathrm{kg} \mathrm{DM})$ contents associated with CS in at least one seasons (i.e., MS/CS, $\mathrm{CS} / \mathrm{MS}$, and CS/CS) may also have contributed to this lack of effect.

An economic analysis of the different nutritional strategies revealed that CS/CS strategy had the highest profitability (i.e., gross revenue, profit, and profit index), despite it showed the greatest EOC and total cost, among the supplementation strategies evaluated (Figure 1). These results are in accordance with those of Silva et al. (2020) findings, who observed that although supplementation costs were higher when animals are supplemented with concentrate in both seasons, unrestricted animals are more profitable when considering the cost per $\mathrm{kg}$ of carcass produced in relation to animals that were subjected to restriction. Furthermore, the use of concentrate supplementation in at least one season is more economically advantageous than the use of mineral supplementation in both seasons, as this practice provides greater hot carcass weight and shorter finishing time for animals in a grazing system (Sampaio et al., 2017).

\section{Conclusions}

The hypothesis of this study was partially accepted due to concentrate supplementation during at least one season (dry or rainy) produces animals with similar meat quality traits and chemical composition of meat, but different hot carcass weight, backfat thickness and hindquarter proportion to those observed when animals were supplemented with concentrate in both seasons. The data also showed that mineral supplementation in both seasons produces animals with the lowest hot carcass weight, backfat thickness and high hindquarter proportion, suggesting a simultaneous qualitative and quantitative restriction under this supplementation strategy. Finally, the economic evaluation of the supplementation strategies revealed that animals kept under concentrate supplementation in both seasons, despite having a high total cost, have great profitability when raised in tropical pasture.

\section{Declarations}

\section{Funding}

This work was supported by the Programa Nacional de Cooperação Acadêmica na Amazônia (PROCAD/Amazônia, Proc. 88887.200488/2018-00 and 21/2018) of the Coordenação de 
Aperfeiçoamento de Pessoal de Nível Superior (CAPES, Brasília, D.F, Brazil), the Fundação Amazônia de Amparo a Estudos e Pesquisa (FAPESPA), and the Conselho Nacional de Pesquisa e Desenvolvimento Científico e Tecnológico (CNPq, Proc. 483926/2013-2).

\section{Conflict of interest}

None.

\section{Ethics approval}

The procedures involving the use of animals were approved by the Ethics Committee on the Use of Animals - CEUA of the Federal Rural University of the Amazon (protocol number: CEUA 020/2016).

\section{Consent to participate}

Not applicable.

\section{Consent for publication}

All authors approve the publication of the manuscript.

\section{Availability of data and material}

The data of this study are available from the corresponding author upon request.

\section{Code availability}

Not applicable.

\section{Authors' contributions}

JMLR: Data collection, Writing- Original draft preparation. JACV: Writing- Original draft preparation, Writing-Reviewing and Editing. EALD: Data collection, Writing- Original draft preparation. NGL: Data collection, Writing- Original draft preparation. RM: Visualization, Writing- Original draft preparation, Writing- Reviewing and Editing. KSA: Data collection, Investigation. LRSO: Data collection, Investigation. JPBL: Data collection, Writing- Original draft preparation. PRS: Writing- Original draft preparation, WritingReviewing and Editing. DIG: Conceptualization of the manuscript, Project administration, Funding acquisition, Supervision, Writing- Original draft preparation.

\section{References}

AOAC - Association of Officiating Analytical Chemists, 2005. Official method of analysis, 18th Edition, (Washington DC, EUA), Method 934.01, 942.05, 984.13 and 920.39. 
BRASIL, 1997. Regulamento da inspeção industrial e sanitária de produtos de origem animal: RIISPOA, Diário Oficial da República Federativa do Brasil, 241.

CIE - Commission Internationale de l'Eclairage, 1986. Colorimetry, 2th Edition, (Viena, AT), Publicação CIE $n^{0} 15.2$.

Culler, R.D., Parrish Jr, F.C., Smith, G.C. and Cross, H.R., 1978. Relationship of myofibril fragmentation index to certain chemical, physical and sensory characteristics of bovine longissimus muscle, Journal of Food Science, 43, 1177-1180.

De Paula, N.F., Paulino, M.F., Couto, V.R.M., Detmann, E., Maciel, I.F.S., Barros, L.V., Lopes, S.A., Valente, E.E.L., Zervoudakis, J.T. and Martins, L.S., 2019. Effects of supplementation plan on intake, digestibility, eating behavior, growth performance, and carcass characteristics of grazing beef cattle, Semina:Ciências Agrárias, 40, 3233-3248.

Detmann, E., Valente, E.E.L., Batista, E.D. and Huhtanen, P., 2014. An evaluation of the performance and efficiency of nitrogen utilization in cattle fed tropical grass pastures with supplementation, Livestock Science, 162, 141-153.

Hopkins, D.L., Martin, L. and Gilmour, A.R., 2004. The impact of homogenizer type and speed on the determination of myofibrillar fragmentation, Meat Science, 67, 705-710.

Hornick, J.L., Van Eenaeme, C., Clinquart, A., Diez, M. and Istasse, L., 1998. Different periods of feed restriction before compensatory growth in belgian blue bulls: I. Animal performance, nitrogen balance, meat characteristics, and fat composition, Journal of Animal Science, 76, 249--259.

Lacerda, N.G., Mezzomo, R., Oliveira, I.M., Alves, K.S., Oliveira, L.R.S., Santos, M.C.A., Lima, R.R.F. and Gomes, D.I., 2021. Pre-slaughter road transportation times: meat quality and sensory properties of Nellore bull meat, Canadian Journal of Animal Science, 1--26.

Ladeira, M.M., Schoonmaker, J.P., Gionbelli, M.P., Dias, J.C.O., Gionbelli, T.R.S., Carvalho, J.R.R. and Teixeira, P.D., 2016. Nutrigenomics and beef quality: A review about lipogenesis, International Journal of Molecular Sciences, 17, 1-21.

Lobato, J.F.P., Freitas, A.K., Devincenzi, T., Cardoso, L.L., Tarouco, J.U., Vieira, R.M., Dillenburg, D.R. and Castro, I., 2014. Brazilian beef produced on pastures: Sustainable and healthy, Meat Science, 98, 336-345 .

Mertens, D.R., Allen, M., Carmany, J., Clegg, J., Davidowicz, A., Drouches, M., Frank, K., Gambin, D., Garkie, M., Gildemeister, B., Jeffress, D., Jeon, C.S., Jones, D., Kaplan, D., Kim, G.N., Kobata, S., Main, D., Moua, X., Paul, B., Robertson, J., Taysom, D., Thiex, N., Williams, J. and Wolf, M., 2002. Gravimetric determination of amylase-treated neutral detergent fiber in feeds with refluxing in beakers or crucibles: Collaborative study, Journal of AOAC International, 85, 1217-1240. 
Modzelewska-Kapituła, M. and Nogalski, Z., 2016. The influence of diet on collagen content and quality attributes of infraspinatus muscle from Holstein-Friesian young bulls, Meat Science, 117, 158-162.

Oksbjerg, N. and Therkildsen, M., 2017. Myogenesis and muscle growth and meat quality. In: P.P. Purslow, New Aspects of Meat Quality: From genes to ethics, (Woodhead Publishing), 33-62.

Pezzopane, J.R.M., Santos, P.M., Cruz, P.G., Bosi, C. and Sentelhas, P.C., 2018. An integrated agrometeorological model to simulate Marandu palisade grass productivity, Field Crops Research, 224, 13-21.

Prado, I.N., Passetti, R.A.C., Rivaroli, D.C., Ornaghi, M.G., Souza, K.A., Carvalho, C.B., Perotto, D. and Moletta, J.L., 2015. Carcass composition and cuts of bulls and steers fed with three concentrate levels in the diets, Asian-Australasian Journal of Animal Sciences, 28, 1309--1316.

Roth, M.T.P., Resende, F.D., Oliveira, I.M., Fernandes, R.M., Custódio, L. and Siqueira, G.R., 2017. Does supplementation during previous phase influence performance during the growing and finishing phase in Nellore cattle?, Livestock Science, 204, 122--128.

Roth, M.T.P., Fernandes, R.M., Custódio, L., Moretti, M.H., Oliveira, I.M., Prados, L.F., Siqueira, G.R. and Resende, F.D., 2018. Effect of supplementation level on performance of growing Nellore and its influence on pasture characteristics in different seasons, Italian Journal of Animal Science, 18, 215--225.

Rubio Lozano, M.S., Ngapo, T.M. and Huerta-Leidenz, N., 2021. Tropical beef: Is there an axiomatic basis to define the concept?, Foods, 10, 1-28.

Rufino, L.M.A., Detmann, E., Gomes, D.I., Reis, W.L.S., Batista, E.D., Valadares Filho, S.C. and Paulino, M.F., 2016. Intake, digestibility and nitrogen utilization in cattle fed tropical forage and supplemented with protein in the rumen, abomasum, or both, Journal of Animal Science and Biotechnology, 7, 1-10.

Sampaio, R.L., Resende, F.D., Reis, R.A., Oliveira, I.M., Custódio, L., Fernandes, R.M., Pazdiora, R.D. and Siqueira, G.R., 2017. The nutritional interrelationship between the growing and finishing phases in crossbred cattle raised in a tropical system, Tropical Animal Health and Production, 49, 1015-1024.

Shang, Y.C., 1990. Partial budget analysis. In: Y.C. Shang, Aquaculture economic analysis: An introduction, (The World Aquaculture Society, Baton Rouge, LA), 47-49.

Silva, L.H.P., Paulino, P.V.R., Assis, G.J.F., Assis, D.E.F., Estrada, M.M., Silva, M.C., Silva, J.C., Martins, T.S., Valadares Filho, S.C., Paulino, M.F. and Chizzotti, M.L., 2017. Effect of post-weaning growth rate on carcass traits and meat quality of Nellore cattle, Meat Science, 123, 192-197.

Silva, L.H.P., Paulino, P.V.R., Benedeti, P.D.B., Estrada, M.M., Alves, L.C., Assis, D.E.F., Assis, G.J.F., Leonel, F.P., Valadares Filho, S.C., Paulino, M.F. and Chizzotti, M.L., 2020. Post-weaning growth rate effects on body composition of Nellore bulls, Animal Production Science, 60, 852-862. 
Steel, R.G.D. and Torrie, J.H., 1980. Principles and procedures of statistics, (McGraw-Hill Book, NY).

Therkildsen, M., 2005. Muscle protein degradation in bull calves with compensatory growth, Livestock Production Science, 98, 205-218.

Therkildsen, M., Houbak, M.B. and Byrne, D.V., 2008. Feeding strategy for improving tenderness has opposite effects in two different muscles, Meat Science, 80, 1037-1045.

Valadares Filho, S.C., Silva, L.F.C., Gionbelli, M.P., Rotta, P.P., Marcondes, M.I., Chizzotti, M.L. and Prados, L.F., 2016. Exigências nutricionais de zebuínos puros e cruzados - BR Corte, 3th Edition, (Suprema Gráfica, $\mathrm{BR})$.

Van Soest, P.J. and Robertson, J.B., 1985. Analysis of forages and fibrous foods, (Cornell University, Ithaca, NY).

Van Soest, P.J., Robertson, J.B. and Lewis, B.A., 1991. Methods for dietary fiber, neutral detergent fiber, and nonstarch polysaccharides in relation to animal nutrition, Journal of Dairy Science, 74, 3583--3597.

Vestergaard, M., Oksbjerg, N. and Henckel, P., 2000. Influence of feeding intensity, grazing and finishing feeding on muscle fibre characteristics and meat colour of semitendinosus, longissimus dorsi and supraspinatus muscles of young bulls, Meat Science, 54, 177-185.

Wicks, J., Beline, M., Gomez, J.F.M., Luzardo, S., Silva, S.L. and Gerrard, D., 2019. Muscle energy metabolism, growth, and meat quality in beef cattle, Agriculture, 9, 1-10.

\section{Figures}




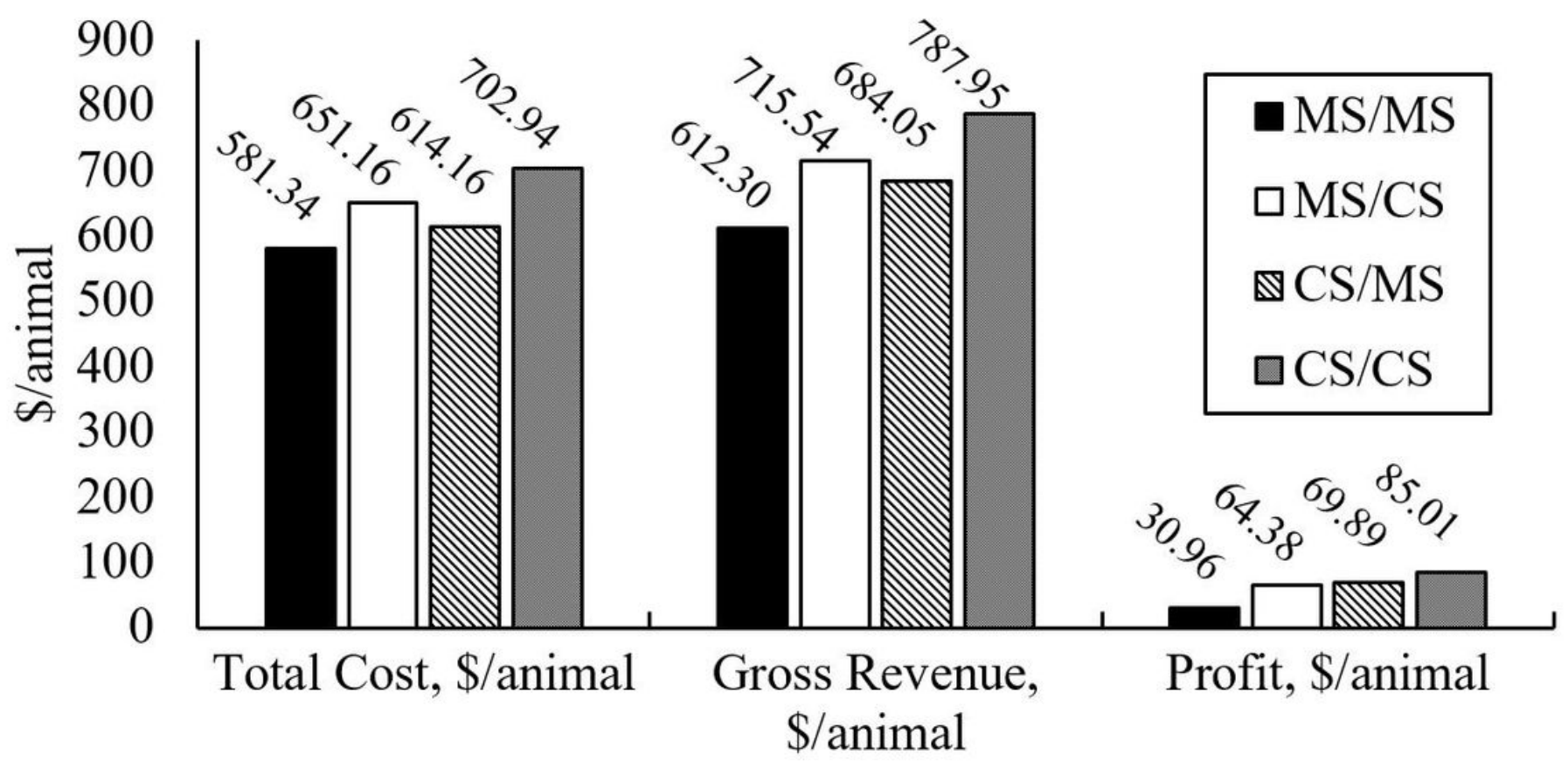

Figure 1

Analysis of total cost, gross revenue, and profit of young Nellore bulls subjected to different supplementation strategies. The values are presented in American dollars.

\section{Supplementary Files}

This is a list of supplementary files associated with this preprint. Click to download.

- 1.1Manuscripteditedturnitin.pdf 